RESEARCH ARTICLE

\title{
Assessing The Impacts of Climate Variability on Rural Households in Agricultural Land Through The Application of Livelihood Vulnerability Index
}

\author{
Ginjo Gitima $^{1} *$ (D), Abiyot Legesse ${ }^{2}$, Dereje Biru ${ }^{3}$ \\ ${ }^{1}$ Department of Geography and Environmental Studies, University of Gondar, P. O. Box 196, \\ Gondar, Ethiopia \\ ${ }^{2}$ Department of Geography and Environmental Studies, Dilla University, P.O. Box 419, Dilla, \\ Ethiopia \\ ${ }^{3}$ Department of Geography and Environmental Studies, Bonga University, P. O. Box 334, \\ Bonga, Ethiopia
}

Received 18 November 2020/Revised 15 April 2021/Accepted 23 April 2021/Published 30 April 2021

\begin{abstract}
Climate variability adversely affects rural households in Ethiopia as they depend on rain-fed agriculture, which is highly vulnerable to climate fluctuations and severe events such as drought and pests. In view of this, we have assessed the impacts of climate variability on rural household's livelihoods in agricultural land in Tarchazuria district of Dawuro Zone. A total of 270 samples of household heads were selected using a multistage sampling technique with sample size allocation procedures of the simple random sampling method. Simple linear regression, the standard precipitation index, the coefficient of variance, and descriptive statistics were used to analyze climatic data such as rainfall and temperature. Two livelihood vulnerability analysis approaches, such as composite index and Livelihood Vulnerability IndexIntergovernmental Panel on Climate Change (LVI-IPCC) approaches, were used to analyze indices for socioeconomic and biophysical indicators. The study revealed that the variability patterns of rainfall and increasing temperatures had been detrimental effects on rural households' livelihoods. The result showed households of overall standardized, average scores of Wara Gesa (0.60) had high livelihood vulnerability with dominant major components of natural, physical, social capital, and livelihood strategies to climate-induced natural hazards than Mela Gelda (0.56). The LVI-IPCC analysis results also revealed that the rural households in Mela Gelda were more exposed to climate variability than Wara Gesa and slightly sensitive to climate variability, considering the health and knowledge and skills, natural capitals, and financial capitals of the households. Therefore, interventions including road infrastructure construction, integrated with watershed management, early warning information system, providing training, livelihood diversification, and SWC measures' practices should be a better response to climate variability-induced natural hazards.
\end{abstract}

Keywords: Households; Livelihood Vulnerability Index; climate variability; Tarchazuria District

*Corresponding author.

Email address : ginjo7205@gmail.com (Ginjo Gitima) 
Ginjo Gitima et al. / Geosfera Indonesia 6 (1), 2021, 96-126

\section{Introduction}

The detrimental effects of climate change and variability have become an environmental and socioeconomic problem that is rapidly causing climate-driven hazards for people around the world (Adu et al., 2018). Globally, climate-related hazards are seen to have a huge impact on young, elderly, poor and marginalized populations such as households headed by women and people with limited access to resources (IPCC, 2014; Tanner et al., 2015; Paul et al., 2019). Climate-related hazards have many indirect impacts on the livelihoods, health, water, agricultural production and socioeconomic welfare of systems (Gezie, 2019; Masuda et al., 2019; Endalew \& Sen, 2020). Climate variability is predicted to increase the frequency and severity of certain severe weather events (IPCC, 2018), and disasters such as floods of agricultural lands, droughts, storms, and cyclones (Ullah et al., 2018). Also, Africa is the utmost vulnerable continent to climate variabilitywith 350-600 million Africans facing increased water stress by the 2050s (Hahn et al., 2009).

Climate change and variability are adversely affecting smallholder farming households in Africa because their activity depends on climate-regulated water resources with low adaptive capacity (Adu et al., 2019). Similarly, dependence on agriculture, pastoralism and lack of irrigation means that African farmers are especially vulnerable to climate hazards (Hahn et al., 2009; Araro et al., 2019). Indeed, rural households' livelihood is considered to be highly vulnerable to climate change and variability (Turpie \& Visser, 2013). This livelihood vulnerability of rural farmers in Africa is triggered by exposure to climate change and variability and by combining social, economic, and environmental factors that interact with it, including Sub-Saharan Africa (Ofoegbu et al., 2017). The agricultural sector in Sub-Saharan Africa is extremely susceptible to potential climate changes and variability (Turpie \& Visser, 2013).

Food insecurity is one of the major drivers that determine development dynamics in East Africa, especially in Ethiopia; due to these the country faces drought and poverty in different periods due to climate changes and variability that was directly affecting the agricultural output (Few et al., 2015; Ademe et al., 2020; Ketema \& Negeso, 2020). Ethiopia is an agro-based economy where agriculture contributes $45 \%$ to the gross domestic product (GDP). The agriculture sector is a source of livelihood for more than $80 \%$ of the population (Dendir \& Simane, 2019). In fact, rain-fed agriculture in the country is more vulnerable to the adverse effects of climate variability (Gezie, 2019) and extreme events like drought and pests (Endalew 
\& Sen, 2020). Even if productivity grew, climate variability would still dramatically impact incountry (Teshome \& Baye, 2018).

In addition, climate change projected in Ethiopia is expected to result in decreased precipitation variability and an increase in temperature $\left(1.1\right.$ to $3.1^{\circ} \mathrm{C}$ by 2060 and 1.5 to $5.1^{\circ} \mathrm{C}$ by 2090) with a rise in the frequency and intensity of extreme events such as flood and drought (National Meteorological Agency, 2007). Other studies indicate an increase of temperature in all seasons of $1.4^{\circ} \mathrm{C}$ to $2.9^{\circ} \mathrm{C}$ by the 2050s (Conway \& Schipper, 2011). Besides, rainfall and temperature patterns show large regional differences (Gezie, 2019). Such trends of increasing temperature, the high variability of precipitation, and the rising frequency of extreme events are expected to continue in the country (Dendir \& Simane, 2019).

Vulnerability assessment approaches tend to be inextricably related to the vulnerability concept and interpretation. In line with, the outcome of vulnerability and its conceptual meanings, Dessai \& Hulme (2004) highlight the different approaches that the two concepts take (without explicitly referring to them) to inform climate adaptation policy. Physical vulnerability concepts prefer to adopt a top-down approach to assessing the strategy of climate adaptation, while vulnerability of contextual concepts focus on socio-economic vulnerability that follow a bottom-up approach (Young et al., 2009). A top-down approach usually starts with international climate forecasts, which can then be rationalized and used to determine climate change's regional effects.An essential feature of bottom-up approaches is primarily the participation of the stakeholders and population of the scheme in classifying climate-change stresses, influences and adaptive strategies (Fellmann, 2012). According to Neupane et al. (2013) socioeconomic parameters such as access to essential resources like forest, land, and water should also be reflected in the vulnerability analysis. Moreover, the importance of incorporating socioeconomic systems with biophysical systems (integrated approach) at varied spatial and social scales in the vulnerability assessment. An integrated approach is effective and may adequately capture all possible dimensions of vulnerability when one integrates both the biophysical (sensitivity and exposure) and the socioeconomic (adaptive capacity) aspects of vulnerability (Endalew \& Sen, 2020).

Studies suggest that poor households' livelihood in rural areas of Ethiopia are the most vulnerable to climate change and variability (Deressa et al., 2009). Similarly, current climate shocks and stresses already have an overwhelming impact on the vulnerability of farmers, 
particularly in rural communities (Sujakhu et al., 2019). Likewise, climate variability vulnerability is understood to be the result of the interaction between the biophysical drivers (include climatic exposure) and the function of the system's sensitivity and adaptive capacity. The exposure constituents entail individuals, biological systems, ecological capacities, services, assets, infrastructure, financial, or social resources in places and settings that could be unfavorably influenced by climate change and variability (Ademe et al., 2020). Sensitivity is the degree to which the rural household is adversely affected by exposure to climatic variables' variations (Teshome, 2017). The adaptive capacity constituent the capacity of systems or people ability, establishments, people, and different ecosystems to conform to potential harm, exploit openings, or react to varied consequences (Amuzu et al., 2018).

Different scholars have been conducted to study the vulnerability of Ethiopian households to climate-related extreme events. For instance, a study conducted by Dercon et al. (2005) using panel data set. However, most of these studies are very general and the results are aggregated at national or regional levels. These studies have also been limited concerned about rural livelihoods vulnerability to climatic-hazards on district and context-specific nature at a local level. In addition, aggregated national results do not capture the complex state of vulnerability at the local level, while they are important to understand development priorities (Simane et al., 2014; Narayanan \& Sahu, 2016). Moreover, the context-specific essence of risk and interventions did not examine the degree to which rural livelihoods in agricultural land are vulnerable to climatic-related extreme events (Ford et al., 2010; Azene et al., 2018).

Hence, our study focuses on livelihood vulnerability to climate variability at contextspecific nature in Tarchazuria district of Dawuro zone. Also, Dendir \& Simane (2019) suggested that stakeholders plan context-specific intervention is important than the national level to reduce rural farmers' vulnerability to climate variability and strengthen farm households' adaptive capacity. Tarchazuria district faced climate-related natural hazards and no study has examined in our study area in local detail. The rural farm households in the district are predominantly rain-fed and hence are prone to risks of climate variability. Due to frequent climatic events like drought, floods, and rainfall irregularities, there are the main problems on indirect costs, crop failure, death of livestock, water shortage, and loss of biodiversity. Moreover, climate variability has also direct and indirect impacts on the prevalence and spread of diseases and pests in the study area. Therefore, this study aimed to assess the impacts of climate variability on rural households 
in agricultural land through the application of the Livelihood Vulnerability Index in the Tarchazuria district of Dawuro Zone.

\section{Methods}

2.1 Biophysical Setting of The Study Area

This study was conducted at Tercha Zuria district in the Dawuro zone of Southwest Ethiopia. Geographically, the study area located between $7^{\circ} 05^{\prime} 00^{\prime \prime}$ to $7^{\circ} 15^{\prime} 00$ "N latitude and $36^{\circ} 45^{\prime} 00^{\prime \prime}$ to $37^{\circ} 20^{\prime} 00^{\prime \prime} \mathrm{E}$ longitude (Figure 1). The study area is located at $510 \mathrm{Km}$ in Southwest of Addis Ababa the capital city of Ethiopia. The district shares borders in the North with Maraka and Tocha district, in the South and Southwest Gojeb river, in the East and Northeast Gena district and in the West Konta special district. The district covers a total area of 588 square kilometers.

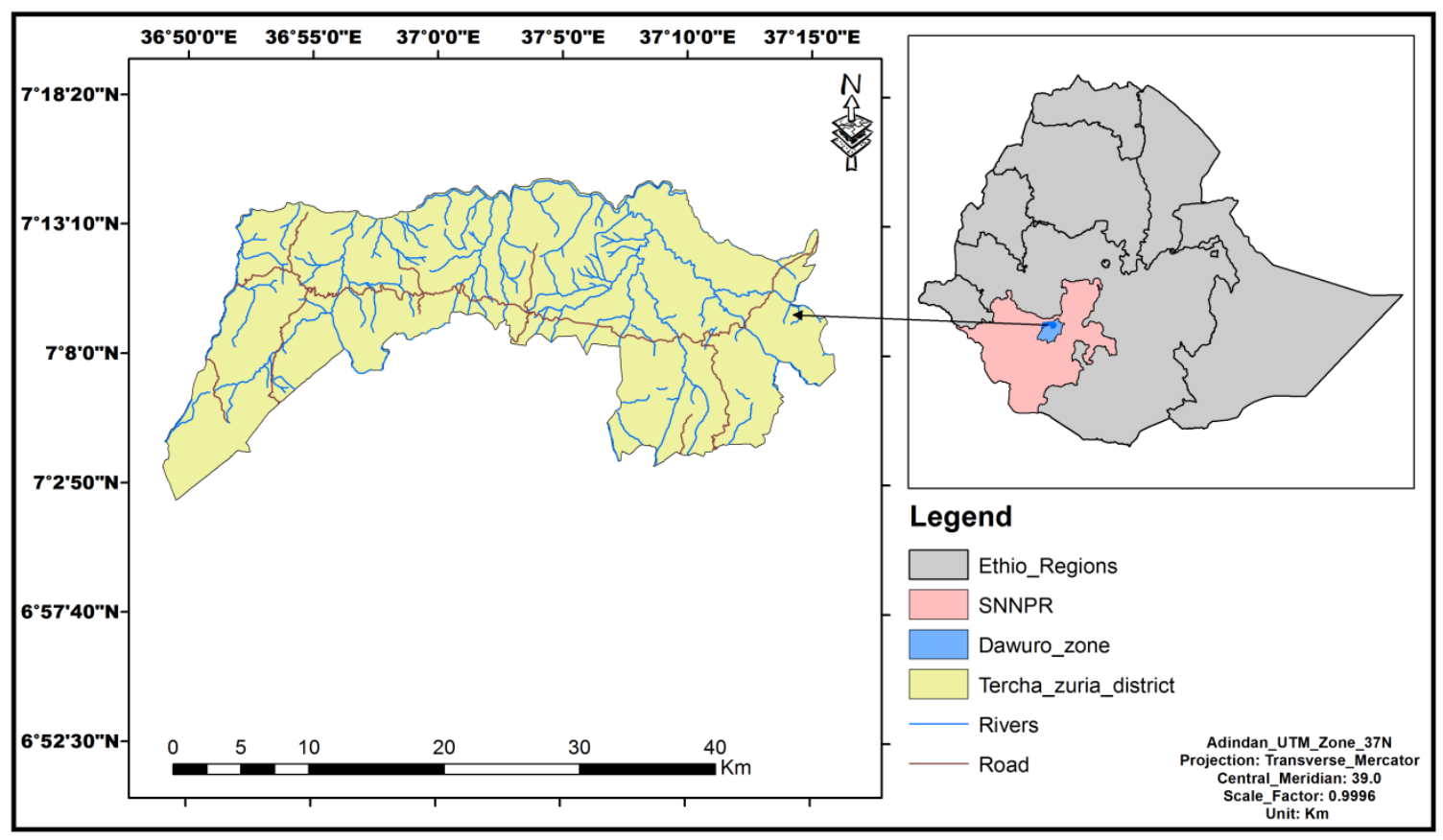

Figure 1. Location of the study area

The physiographic setting of the study area is a dissected and rugged landscape, having well-drained and moderately weathered brown soil (Nitisols) and Orthic Acrisols. Thus, soil erosion and floods in the area is mainly attributed to the dissected and rugged topography. The geology of the study area is abundant with rhyolites and trachy basalts mainly overlying in the Precambrian basement and tertiary volcanism (Bore \& Bedadi, 2015; Gitima \& Legesse, 2019). 
The elevation ranges lie between $918 \mathrm{~m}$ to $2170 \mathrm{~m}$ above sea level. The dominant agro-ecology in the districtis tropical (kola) and sub-tropical (Woina-dega) agro-climate. The average annual minimum and maximum temperatures of 13 years were $14.65^{\circ} \mathrm{C}$ to $16.12^{\circ} \mathrm{C}$ and $26.4^{\circ} \mathrm{C}$ to $29.3^{\circ} \mathrm{C}$, respectively. The 13 years (2007-2019) of mean annual rainfall was $1398.8 \mathrm{~mm}$, and the mean monthly rainfall ranges between $18.6 \mathrm{~mm}$ and $323 \mathrm{~mm}$ (National Meteorological Agency, 2019). The rainfall is a bimodal type in the study area: the short rainy season is between March and May, and the long rainy season between June and September (Bore \& Bedadi, 2015).

Agriculture is mainly composed of crop production and animal husbandry and it is the main source of livelihood of the population in the district. The dominant activities under land use pattern in the study area include the cultivation of perennial crops such as enset (Enseteventricosum), banana, coffee, mango, avocado and etc. Whereas the annual food crops, including cereals (maize, sorghum, teff), pulses (beans, peas), (maize and teff are largest produced), and root crops like potatoes, yams, sweat potatoes and cassavas. Generally, mixed agriculture is the major economic activity in the study area (Gitima \& Legesse, 2019). However, the watershed has ample potential for cultivations, its farm productivity is very low because farmers use traditional means of production. Besides, crop production is mainly rain-fed coupled with poor market access makes the livelihood of farming households extremely stagnant (Abebe, 2014).

\subsection{Data Sources and Collection Tools}

The data required for the current study is obtained from both primary and secondary sources and also these necessary data were of both qualitative and quantitative in nature. The primary data were collected through the questionnaire, key informant interviews, FGDs, and field observations. Questionnaire was used to collect information from the sampled rural households. Prior to the survey, the enumerators were trained how to interview and fill the questions. Close-ended and open-ended format questions were prepared to the selected sample rural household heads and administered through face-to-face interview to get information about the impacts of climate variability on rural household livelihoods. Also, two focus group discussions, the discussion among a small group of six to seven members of the farmers were carried out in the district. In addition, key informant interviews were held with respondents from different sections of the community such as three development agents, two from non-government 
organizations, four model farmers, and three elderly farmers. Moreover, secondary data were collected from published and unpublished documents. Furthermore, time series climatic data such as temperature and rainfall were obtained from the regional meteorological agency (Hawassa) to predict the trend and variability over time. The reference periods for the climatic data were between 2007 and 2019. This range was chosen based on the concept of climate variability and its resulting effects on the rural livelihoods in agricultural land.

\subsection{Research Design and Sampling Procedure}

This study employed a cross-sectional survey research design and longitudinal time series meteorological data were used records over the period of 2007-2019. In selecting representative sample households, multistage sampling techniques were carried out to select sample household heads for the study from the district. The first stage, Tarchazuria district, was selected using purposive sampling techniques among the ten districts of Dawuro zone because in the district rural farmers' livelihoods affected by climate variability like drought and extreme events, and climate data availability and meteorological station in the area. Secondly, two kebeles were purposively selected using on the above district selection technique i.e., : Mela Gelda (372 household heads) and Wara Gesa (464 household heads).Finally, simple random sampling procedure was applied to select 270 representative farm household heads for the study.

\subsection{Methods of Data Analysis}

The unit of analysis of this study focused on rural farm household heads. Qualitative data were analyzed by using thematic analysis of categorization; the data were gathered through observation, interview and focus group discussions. Quantitative data were analyzed by descriptive statistics such as percentage, mean, ratio, maximum, and minimum by using Microsoft Excel. Metrological data such as rainfall was analyzed by using standardized precipitation index and coefficient of variation $(\mathrm{CV})$, whereas, temperature was analyzed by means of simple linear regression and standardized temperature anomalies. Household Exposure (HE) and household Sensitivity (HS) indices complemented with basic household information of farmers were analyzed using descriptive statistics. 


\subsubsection{Simple Linear Regression}

It is the mainly used to analyze the association between one quantitative result and a single quantitative explanatory indicator. The method is important to detect and characterize the long-term trend and variability of temperature and rainfall values at the annual/monthly time scale. The parametric test takes into account random variable $\mathrm{Y}$ on time $\mathrm{X}$ in a simple linear regression. The regression line slope coefficient was interpolated that computed from the data is a coefficient of the regression or the Pearson correlation coefficient (Teshome, 2017). It can be calculated with eq. 1:

$\mathrm{Y}=\alpha+\beta x$

Where: $Y$ refers natural disasters (rainfall and temperature variability) during the period; $\alpha$ is constant of regression; $\beta$ represents slope of the regression equation; $x$ refers to number of years from 2007 to 2019.

\subsubsection{Standardized Precipitation Index (SPI)}

Standardized Precipitation Index (SPI) developed by the (World Meteorological Organization, 2012). The number of cold nights and warm days per month was calculated using the monthly observation of minimum and maximum temperature, respectively. The SPI was used to identify droughts across the years from 2007 to 2019. It is a statistical measure indicating how unusual an event is, making it possible to determine how often droughts of certain strength are likely to occur. The practical implication of SPI-defined drought, the deviation from the normal amount of precipitation, would vary from one year to another. It can be calculated with eq. 2 :

$S P I=\frac{x i-\bar{x}}{\delta}$

where; SPI= anomaly of rainfall (irregularity) in different time period; xi is yearly rainfall in the study period; $\bar{x}$ is the long-term average yearly rainfall; and $\delta$ is the standard deviation of rainfall in observed time period (Teshome, 2017). Accordingly, the drought severity classes are: extreme drought (SPI <-1.65), moderate drought (-0.84 >SPI > -1.28), severe drought (-1.28> SPI > 1.65) and no drought (SPI >-0.84) (World Meteorological Organization, 2012). 


\subsection{Constructing Livelihood Vulnerability Index}

Vulnerability is one factor determining whether people have risks to their livelihoods in agricultural land or not (Suryanto \& Rahman, 2019). Thus, the index is used for comparison among the communities. In addition, the Sustainable Livelihood Framework (SLF) where vulnerability context is the major determinant of sustainability of livelihood assets as it directly influences livelihood strategies, institutional process, and livelihood outcomes of the community. The effects of climate change and variability on farmers' livelihoods have been considered under the vulnerability context of the Sustainable Livelihood Framework or SLF (Can et al., 2013).

The Livelihood Vulnerability Index calculations developed by Hahn et al. (2009) is applied in this study, which consists of the following six main components: These are livelihood assets of Sustainable Livelihood Framework such as human, physical, social, natural and financial capital. In addition to these, we added one main component i.e., livelihood strategies. The sub-components have been developed as indicators under a single component.

Vulnerability to variability is determined by a complex interrelationship between multiple factors where few factors are not often directly quantifiable. Vulnerability assessment requires a detailed contextual understanding of the relevant systems and how structural changes impact them. The vulnerability assessment involves estimation of the vulnerability level of a community and its contributing factors through the development of indices following three steps. The first step identifies the indicators. Next, using the actual, minimum, and maximum sub-component indicators, the standardized index value for the sub-component indicators is calculated. Finally, the standardized major component indices are calculated and aggregated to form an overall index (Endalew\& Sen, 2020). Therefore, the vulnerability indicators and measurements were identified, operationalized, and hypothesized in table 1. 
Table 1. Vulnerability indicators and hypothesized functional relationships

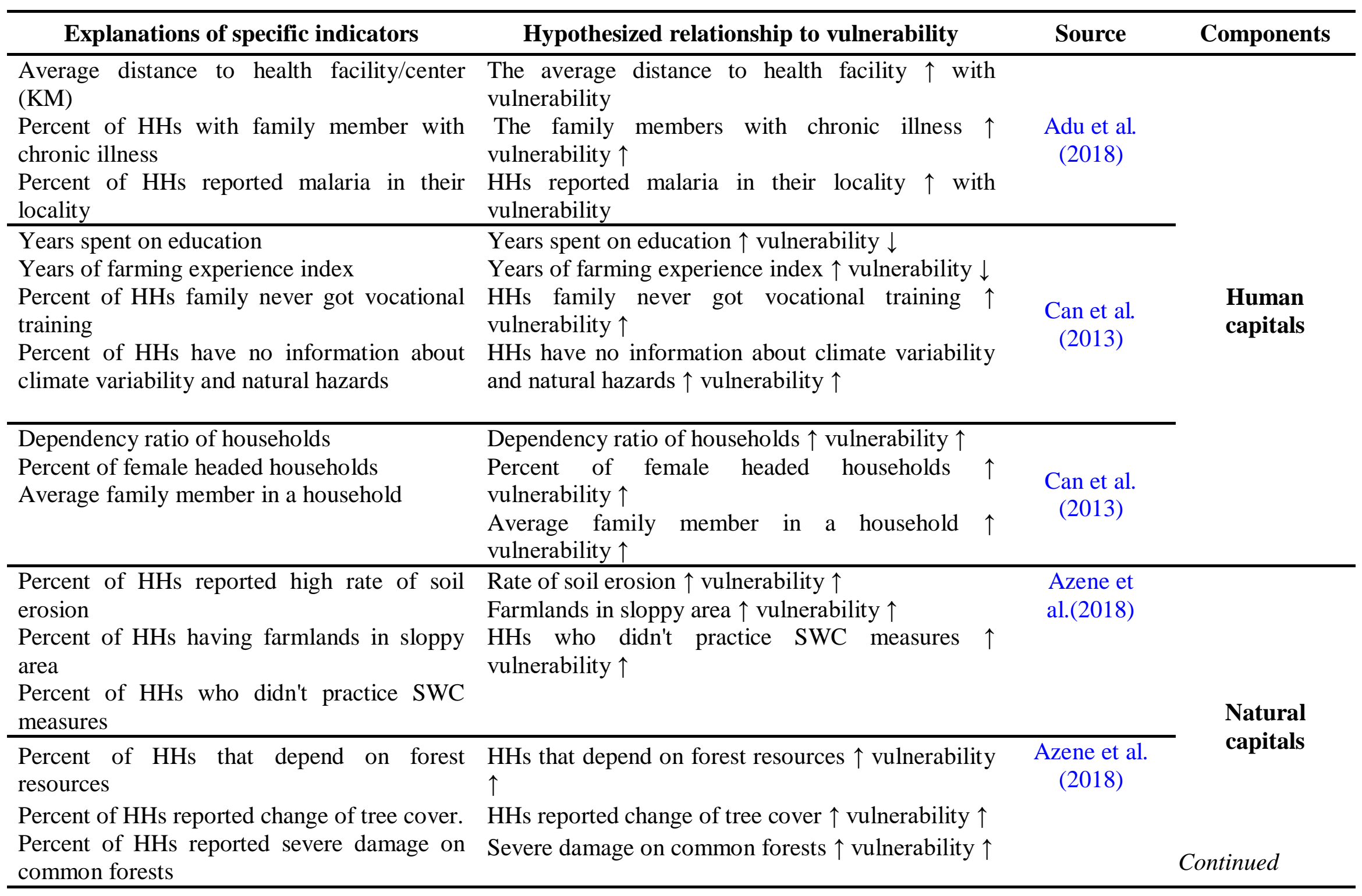




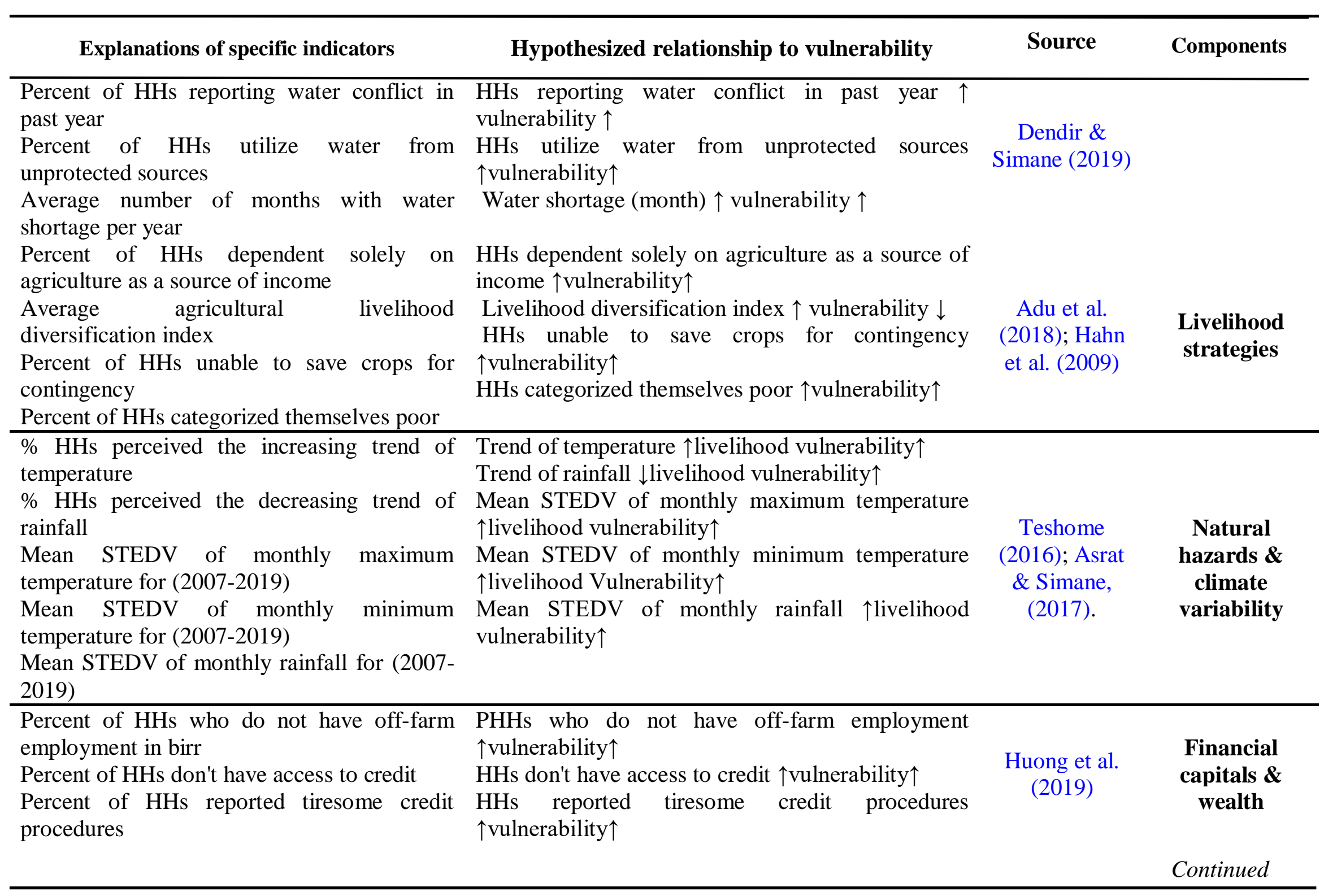




\begin{tabular}{|c|c|c|c|}
\hline Explanations of specific indicators & Hypothesized relationship to vulnerability & Source & Components \\
\hline $\begin{array}{l}\text { Livestock ownership in TLU } \\
\text { Average land hold size in ha } \\
\text { Average yearly off-farm income in birr }\end{array}$ & $\begin{array}{l}\text { Livestock ownership in TLU } \uparrow \text { vulnerability } \downarrow \\
\text { Average land hold size } \uparrow \text { Vulnerability } \downarrow \\
\text { Average yearly off-farm income } \uparrow \text { vulnerability } \downarrow\end{array}$ & $\begin{array}{c}\text { Asrat \& } \\
\text { Simane (2017) }\end{array}$ & \\
\hline $\begin{array}{l}\text { Percent of HHs house roof made of grass } \\
\text { Percent of HHs house located in hazard prone } \\
\text { /slope areas } \\
\text { Percent of HHs that with housing affected by } \\
\text { flood in last } 5 \text { years }\end{array}$ & $\begin{array}{l}\text { HHs house roof made of grass } \uparrow \text { vulnerability } \uparrow \\
\text { HHs house located in hazard prone /slope areas } \\
\uparrow \text { vulnerability } \uparrow \\
\text { HHs that with housing affected by flood in last } 5 \\
\text { years } \uparrow V u l n e r a b i l i t y \uparrow\end{array}$ & - & \multirow[b]{2}{*}{$\begin{array}{l}\text { Physical } \\
\text { capitals }\end{array}$} \\
\hline $\begin{array}{l}\text { Average time to reach market in minute } \\
\text { Percent of HHs no transport access all the } \\
\text { year } \\
\text { Percent of HHs reported challenged by public } \\
\text { road } \\
\text { Average distance to agricultural inputs in } \\
\text { minute }\end{array}$ & $\begin{array}{l}\text { Average time to reach market in minute } \uparrow \\
\text { vulnerability } \uparrow \\
\text { HHs no transport access all the year } \uparrow \text { vulnerability } \\
\uparrow \\
\text { HHs reported challenged by public road } \uparrow \\
\text { vulnerability } \uparrow \\
\text { Average distance to agricultural inputs in minute } \uparrow \\
\text { vulnerability } \uparrow\end{array}$ & $\begin{array}{l}\text { Huong et al. } \\
\qquad(2019)\end{array}$ & \\
\hline $\begin{array}{l}\text { Percentage of households not associated with } \\
\text { any } \\
\text { Organization/cooperatives } \\
\text { Percent of HHs have loose ties to } \\
\text { relatives/neighbors }\end{array}$ & $\begin{array}{l}\text { HHs not associated with any } \\
\text { organization/cooperatives } \uparrow \text { Vulnerability } \uparrow \\
\text { HHs have loose ties to relatives/neighbors } \uparrow \\
\text { vulnerability } \uparrow\end{array}$ & $\begin{array}{l}\text { Panthi et al. } \\
\text { (2016) }\end{array}$ & \multirow[t]{3}{*}{ Social capitals } \\
\hline $\begin{array}{l}\text { Percent of HHs not member of credit \& } \\
\text { saving group } \\
\text { Percent of HHs not member of religious } \\
\text { groups }\end{array}$ & $\begin{array}{l}\text { HHs not member of credit \&saving group } \uparrow \\
\text { vulnerability } \uparrow \\
\text { HHs not member of religious groups } \uparrow \text { vulnerability } \\
\uparrow\end{array}$ & - & \\
\hline $\begin{array}{l}\text { Percent of HHs not member of other } \\
\text { organization (idir or ikub) }\end{array}$ & $\begin{array}{l}\text { HHs not member of other organizations } \uparrow \\
\text { vulnerability } \uparrow\end{array}$ & & \\
\hline
\end{tabular}


Explanations of specific indicators

Percent of HHs feel insecurity of farmland Percent of HHs don't encouraged by land certificate

Percent of HHs have no regular information from government policies

Percent of HHs not visited by DAs in a cropping season

Percent of HHs unhappy by their local

leaders' decisions

\section{Hypothesized relationship to vulnerability}

HHs feel insecurity of farmland $\uparrow$ vulnerability $\uparrow$

HHs don't encouraged by land certificate $\uparrow$

vulnerability $\uparrow$

HHs have no regular information on government

policies $\uparrow$ vulnerability $\uparrow$

HHs not visited by DAs in a cropping season $\uparrow$

vulnerability $\uparrow$

HHs unhappy by their local leaders' decisions $\uparrow$ vulnerability $\uparrow$

Note: HHs households, $\uparrow$ increases, $\downarrow$ decreases and idir and ikub are local/traditional institutions/organizations 


\subsection{Calculating the Livelihood Vulnerability Index}

\subsubsection{Composite Index Approach}

Both equal and unequal weighting schemes are the two most common methods for combining indicators. In the first step, each indicator is given equal weight. In the second step, expert opinion, complex fuzzy logic, or principal component analysis are all used to assign different weights to various indicators (Hahn et al., 2009). We used both equal and unequal weights in this study, then used an integrated method to compute composite vulnerability indices using weighting average systems.

According to Adu et al. (2018), a single component is consisting several subcomponents (indicators), each of these indicators is calculated on a different scale, such as percentages or ratios and etc., therefore, it was necessary to the data into indices using either eq. (3) or eq. (4).

Index Shi $=\frac{\mathrm{s}_{\mathrm{h}}-\mathrm{S}_{\min }}{\mathrm{S}_{\max }-\mathrm{S}_{\min }}$.

Index $_{\text {Shi }}=\frac{S_{\max }-S_{h}}{S_{\max }-S_{\min }}$.

Where; $S_{h}=$ observed sub-component of indicator for household and $S_{\min }$ and $S_{\max }$ are the maximum and minimum values, respectively (Adu et al., 2018).

Using eq. (5) to obtain the index of each major component (the sub-component indicators were averaged) :

$$
\mathrm{M}_{\mathrm{h}}=\frac{\sum_{\mathrm{i}=1}^{\mathrm{n}} \text { Index }_{\text {Shi }}}{\mathrm{n}} .
$$

where six major components (Human capital $(\mathrm{H})$, Natural capital $(\mathrm{N})$, Social capital $(\mathrm{S})$, Physical capital (P), Financial capital (F) were calculated using $\mathrm{M}_{\mathrm{h}}$ is and livelihood strategies (LS)) for household h, Index ${ }_{S h i}$ consist of the sub-components, indexed by i. Then, six major component were averaged with eq. (6) to find the district-level LVI (Adu et al., 2018):

$$
\mathrm{LVI}_{\mathrm{h}}=\frac{\sum_{i=1}^{6} w_{M i} M_{h i}}{\sum_{i=1}^{n} w_{M i}}
$$

which can be also expanded as: 
$L V I_{h}=\frac{w_{H} H_{h}+w_{N} N_{h}+w_{S} S_{h}+w_{P} P_{h}+w_{F} F_{h+w_{L S} L S_{h}}}{w_{H}+w_{N}+w_{S}+w_{P}+w_{F}}$

\subsubsection{Calculating the LVI-IPCC: IPCC Framework Approach}

According to Hahn et al. (2009), suggest an alternative approach to measuring the LVI. Table 2 explain the major components' organization. Table 1 (the same subcomponents outlined) were used in Eq. (3), (4), and (5) to calculate the LVI-IPCC. When the major components are combined, the LVI-IPCC diverges from the LVI (Hahn et al., 2009).

Table 2. Categorization of major components into contributing factors from the IPCC

\begin{tabular}{ll}
\hline IPCC contributing factors to vulnerability & \multicolumn{1}{c}{ Major components } \\
\hline Exposure (e) & Natural disasters and climate variability \\
& \\
Adaptive capacity (a) & Socio-demographic profile \\
& Livelihood strategies \\
& Social networks \\
& \\
Sensitivity (s) & Health, knowledge and skills \\
& Natural capital \\
& Financial capital \\
\hline
\end{tabular}

Source: Adopted from Can et al. (2013)

They are combined according to the categorization scheme in Table 2, using the following equation:

$C F_{h}=\frac{\sum_{i=1}^{n} w_{M i}{ }^{M} h i}{\sum_{i=1}^{n} w_{M i}}$.

Where; $\mathrm{CF}_{\mathrm{h}}$ is an IPCC defined contributing factor (exposure, sensitivity and adaptive capacity) for rural households $h, M_{h i}$ are main components for household $h$ is indexed by $i$, $w_{M i}$ is the weight of every main component, and $n$ is the number of main components in every factor with contribution. When exposure, sensitivity, and adaptive capacity were combined in calculation, the formula developed by Hahn et al. (2009) combining the three contributing factors using:

$L V I-I P C C_{h}=\left(e_{h}-a_{h}\right) * S_{h}$

where; LVI-IPCC $h$ indicates the LVI for household $\mathrm{h}$ represented using the IPCC vulnerability framework, $e$ is the households' exposure result, $a$ is households' the capacity of adapative result, and $s$ is the household's sensitivity result (weighted mean score of the health, knowledge, skills, natural capital and financial major components) which ranged from 
$(-1)$ the least vulnerable to $(+1)$ the most vulnerable on the LVI-IPCC scale (Adu et al., 2018).

\section{Results and Discussion}

\subsection{Maximum And Minimum Temperatures Over The Last 13 Years}

The average temperature hurts agricultural output and significantly reduces agricultural output. A one percent increase in average temperature would reduce agricultural output by $2.5 \%$ in the long run. The long-run elasticity of agricultural output concerning average temperature is -2.5 indicating that agricultural output is most sensitive to an average temperature increase in the long run. A decrease in agricultural productivity is likely as a result of increased temperature variability. This may be due to the fact that high temperatures deplete soil nutrients, making livestock and agricultural productivity difficult (Ketema \& Negeso, 2020). Climate variability causes the frequency and severity of weather events.

Accordingly, an analysis of the climate variability in the study area over the last 13 years (2007-2019) found that the maximum and minimum mean temperatures were increased over time. In a way that simple linear regression shows about 0.66 and 0.36-degree centigrade has been increased to the mean maximum and minimum temperatures of the study area per decade, respectively. This shows that the district had been in a warming trend for the last thirteen years (2007 to 2019). These results also confirm the survey results in terms of the respondents' perceived increment trends of the temperature over the last 13 years. Moreover, key informants' interviewers indicated the increasing trends of temperature and shifting of seasonal weather phenomenon causes the spreading of tropical diseases like malaria and locust. Furthermore, FGDs discussants claimed that rise of temperature and its adverse effects on crop production is increasingly being felt. These show the main evidence of the impacts of climate variability on rural livelihoods in the district.

As shown in figure 2, the maximum and minimum deviations in temperature over the last thirteen years (2007 to 2019) are clearly shown. Maximum temperature deviations decreased in 2007, and in 2008 minimum temperature increases were observed from the long average temperature. Whereas, both maximum and minimum temperature deviations were shows to rise and fall in 2009 and 2010, respectively. From 2011 to 2012 temperature deviations continued with fluctuation. But from 2013 to 2015 the deviations of minimum temperatures rapidly decreased. From 2017 until 2019 the minimum temperature deviation slightly went upwards from the study area's long-term average temperature. 


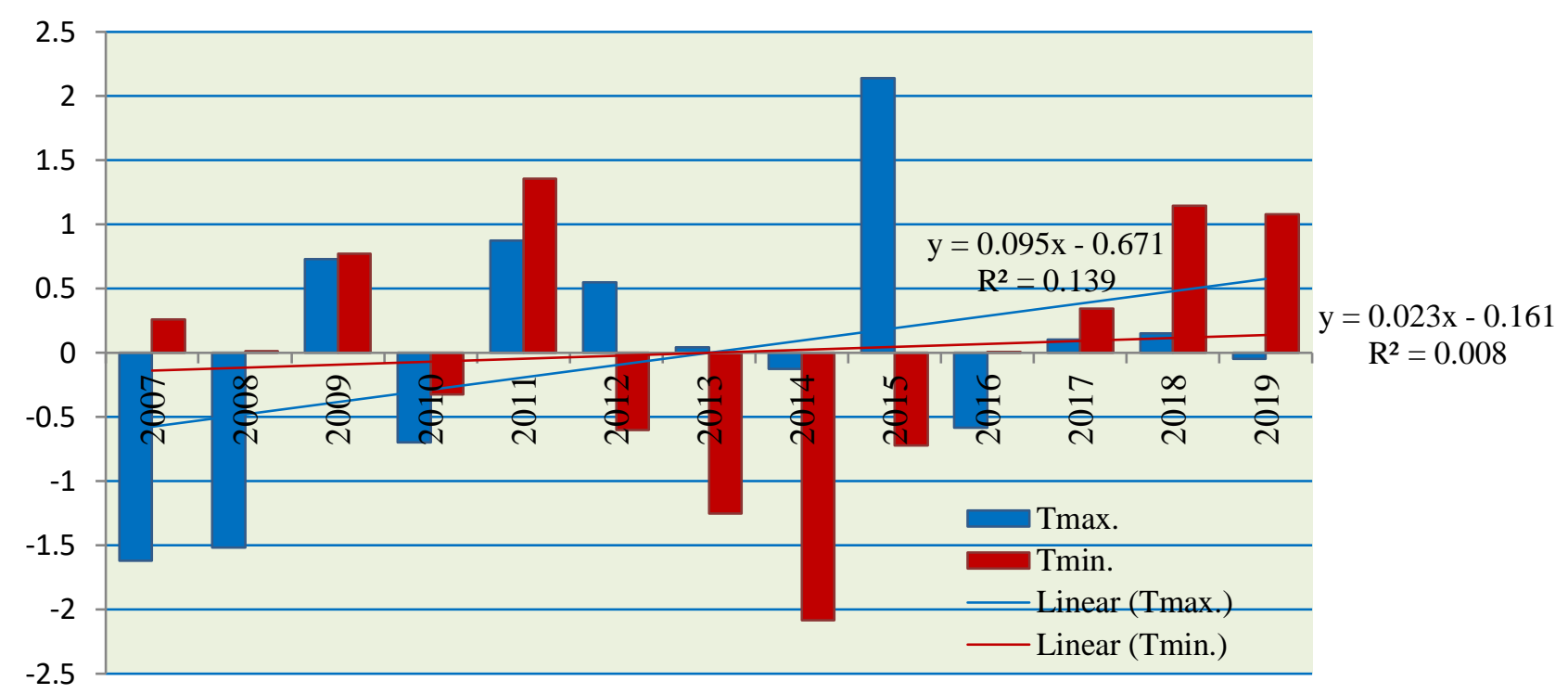

Figure 2. Deviations of maximum and minimum temperatures in the study area

As shown in figure 3 the least mean monthly minimum temperature was recorded from 2007 to 2019 in July $\left(14.62^{\circ} \mathrm{C}\right)$, August $\left(14.7^{\circ} \mathrm{C}\right)$, and September $\left(14.68^{\circ} \mathrm{C}\right)$. Whereas, the highest minimum temperatures were recorded in the study area in January $\left(16.3^{\circ} \mathrm{C}\right)$, February $\left(16.8^{\circ} \mathrm{C}\right)$, and March $\left(16.5^{\circ} \mathrm{C}\right)$ from 2007 to 2019 . The highest mean monthly maximum temperature was recorded in January $\left(29.75{ }^{\circ} \mathrm{C}\right)$, February $\left.30.46{ }^{\circ} \mathrm{C}\right)$ and March $\left(30.5{ }^{\circ} \mathrm{C}\right.$ ) for the period of 2007 to 2019. While, the least mean monthly maximum temperature was recorded in July $\left(24.6{ }^{\circ} \mathrm{C}\right)$, August $\left(25^{\circ} \mathrm{C}\right)$, and September $\left(25.6^{\circ} \mathrm{C}\right)$. Similarly, the study made by Kedir \& Tekalign (2016) in the pastoral community of the Karrayu people in the Oromia region reported that the mean maximum monthly temperature indicates an increasing trend except for July and August.

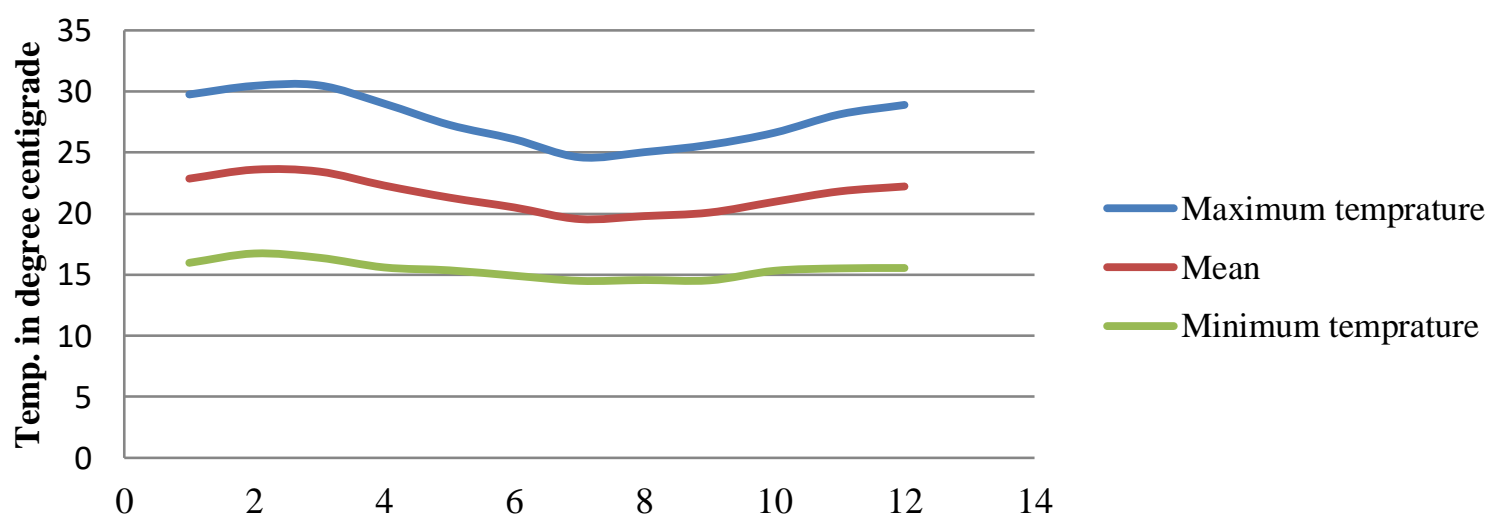

Figure 3. Mean monthly minimum and maximum temperatures 


\subsection{Rainfall Anomaly Over The Last 13 Years: Standardized Precipitation Index (SPI)}

Rainfall in Ethiopia is a major input in determining output due to this the country is named as rain-fed agriculture, where rainfall play an important role (Ketema \&Negeso, 2020). As shown in figure 4 the analysis of metrological data of rainfall indicates the annual temporal variations. The annual rainfall variability from 2007 through 2019 can be detected from the CV value. The result showed that the study area's annual temporal CV was 19.5 percent, indicating a low variability in rainfall. According to Asfaw et al. (2018), CV below $20 \%$ implies less variability and hence annual rainfall experienced less variability. However, key informant interviewers indicated that climate variability has become unpredictable and associated with erratic rainfall. They also claimed that rainfall's erratic nature brings indescribable hardship to study communities as most of them expressed unhappiness to the current irregular, and unstable nature of rainfall currently experienced. Similar findings have been found by Araro et al. (2019) in Konso district of Southern Ethiopia, unexpected rain followed by heavy flood and drought. These variations in rainfall pattern have a direct impact on crop yields, livestock production and price fluctuation from the agricultural perspective. Also, FGDs discussants reported there is a high variability of rainfall and rainy seasons could either delay when farmers predict a fall of rains when they least expected them in the district. Therefore, FGDs discussants suggested livelihood diversification strategies, and water harvesting methods during the rainy seasons should be the best options to adapt to existing rain variability and extreme weather events. Likewise, Kedir \& Tekalign (2016) suggested that proper use of water harvesting technology should be devised to use and manage the intense rainfall of July and August in their study in central Ethiopia. Moreover, early warning systems and integrated watershed and environmental management measures are required to minimize/avoid disaster and design possible remedial actions.

The rainfall anomaly also witnessed for the presence of annual variability and the trends being below the long-term average. As shown in figure 4, the SPI (rainfall anomalyvariability and irregularity) can identify and monitor droughts. The evaluation of SPI at a certain location is based on a series of accumulated rainfall for a different monthly time scale in a year. The rainfall series is fitted to probability distributions that are subsequently transformed into normal distributions. It follows that the average SPI for the target location and the chosen period is zero. Negative SPI numbers specify less than median or long-term average rainfall, whereas positive SPI values indicate greater than median rainfall (Mohammed \& Scholz, 2019).

Figure 4 also clearly shows the variation of rainy years (wet) and years of drought (dry) episodic pattern. The results of the last 13 years indicated; seven years $(53.8 \%)$ received 
below the long-run average rainfall whereas 6 years (46\%) obtained above long-term average rainfall. Of the major drought events, such as 2007, 2008, and 2009, have been observed in the study period. This implies the district received below the long-term mean rainfall, but their severities were different based on SPI. The 2007 rainfall amount emerged as the lowest record in the observation period, and according to the drought severity classes used by Azene et al. (2018), the year 2007 marked the extreme drought year in the study area. The result also indicated that the years 2010 to 2014 received surplus rainfall from the average mean with positive SPI values. This identified the probability of the highest erosion and flood occurrences in the district, but its occurrence was not recorded. Consecutive negative SPI values were observed from 2015 to 2018 followed in 2019 slightly recorded above normal average rainfall (figure 4).

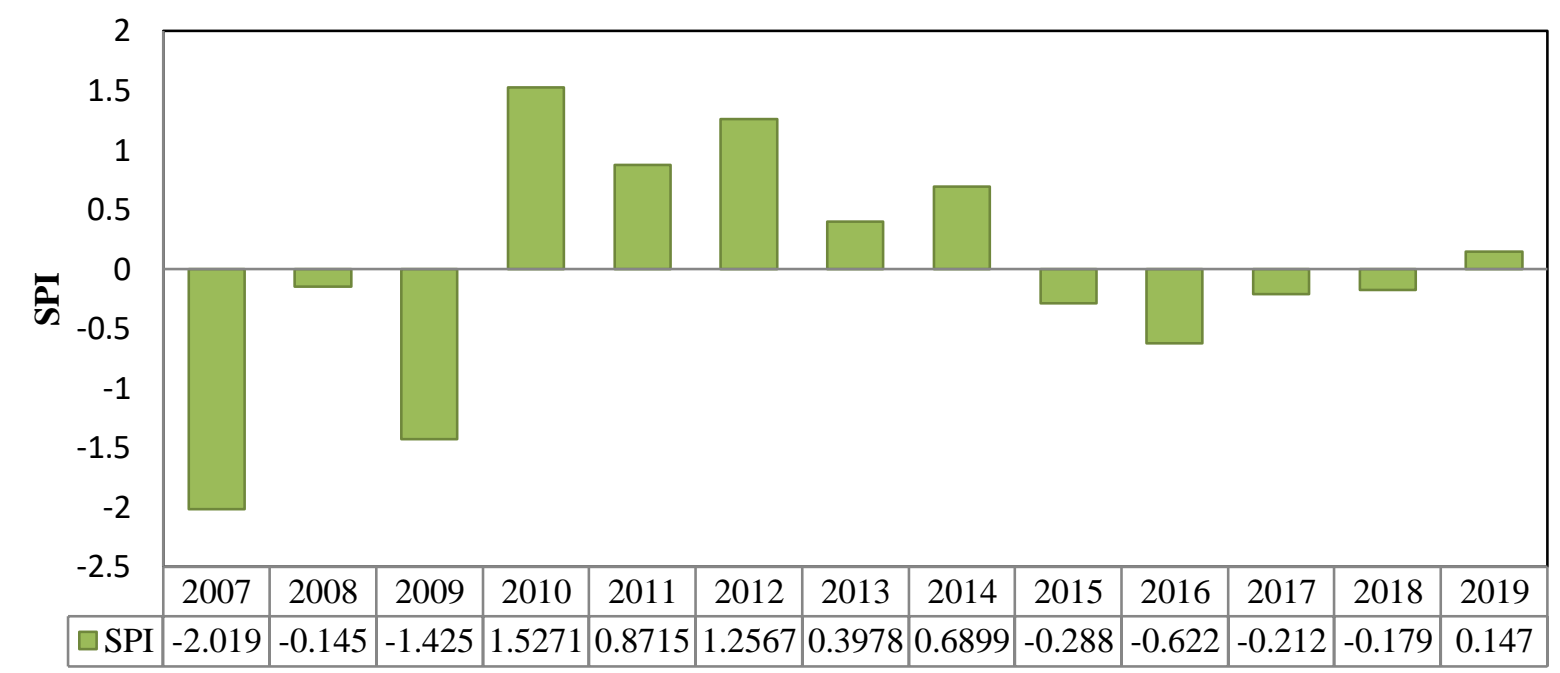

Figure 4. Standardized precipitation index (SPI) for the study area

\subsection{Monthly Standard Deviations of Rainfall}

The result in table 3 shows that the rainfall data recorded in 2007-2019 are characterized by a significant variability of monthly rainfall in the district. The lowest average rainfalls were recorded among the months whereby January $(18.6 \mathrm{~mm})$, February $(24.87 \mathrm{~mm})$, and November $(39.5 \mathrm{~mm})$ followed in March $(44.3 \mathrm{~mm})$. Whereas, the highest average monthly rainfall was recorded in August (323 mm), July (299.5 mm), and September (297.4 mm), followed by May (289.7 mm) in study period between 2007 and 2013.

The standard deviation is one way of summarizing the spread of a probability distribution; it directly related with the degree of uncertainty allied thru predicting the value of a random variables. High values indicate more uncertainty than low values (Teshome, 2016). Accordingly, May (129.6), April (79.5), and October (77.8) had the highest standard deviation indicates more uncertainty in the district (Table 3). While, January (18.7), 
November (22.84), and February (26.3) and the lowest standard deviations followed by December (43.7). It has been observed from the study that rainfall is generally at its peak among August, July, and September, receiving more than three fourth of the amount of rainfall in these months.

Table 3. Monthly mean rainfall, standard deviations, coefficient of variations and rainfall coefficient for 2007-2019

\begin{tabular}{lcccccccccccc}
\hline Month & Jan. & Feb. & Mar & Apr. & May & Jun. & Jul. & Aug. & Sept. & Oct. & Nov. & Dec. \\
\hline $\begin{array}{l}\text { Mean } \\
\text { (mm) }\end{array}$ & 18.6 & 24.87 & 44.3 & 172.8 & 289.7 & 217.6 & 299.5 & 323 & 297.4 & 128.4 & 39.5 & 47.9 \\
STEDV & 18.7 & 26.3 & 55 & 79.5 & 129.6 & 60.7 & 75 & 75.3 & 97.3 & 77.8 & 22.84 & 43.7 \\
CV & 1.0 & 1.06 & 1.3 & 0.46 & 0.45 & 0.28 & 0.25 & 0.23 & 0.33 & 0.60 & 0.58 & 0.92 \\
\hline
\end{tabular}

Note: STEDV=Standard deviations of each month, $\mathrm{CV}=$ Coefficient of variation

3.4 Households' Livelihood Vulnerability Index (LVI)

Practically, assessment of livelihood vulnerability is too complicated and difficult to be covered all because there are many aspects, dimensions and factors that relating to livelihood vulnerability, e.g., economic, political, demography, etc., and it was certainly mentioned in some reports (Can et al., 2013). This study only focuses on some major components that influence rural livelihoods in agricultural lands of households due to climate variability in the Tercha District of Dawuro zone.

The results of LVI standardized average scores of all 13 indexed major components calculated from 45 subcomponents or indicators commune are presented collectively in Table 4. The indices being relative values were compared across the two kebeles such as Wara Gesa and Mela Gelda. Overall Wara Gesa (0.60) households had a high livelihood vulnerability index with dominant major components of natural, physical, social capital, and livelihood strategies than Mela Gelda (0.56). An indexed major component range of (0.50) to (0.73) and (0.38) to (0.62) in Wara Gesa and Mela Gelda, respectively, showing a high degree of vulnerability to climate variability-related natural hazards.

\subsubsection{Human Capital Vulnerability}

As indicated in table 4, the indexed capital as human capital consisted of three major components and ten indicators. The vulnerability index of the LVI's human capital major components showed that Mela Gelda (0.59) was more vulnerable to climate variability than Wara Gesa (0.52). A higher number of households causes the higher vulnerability on the health component index of Mela Gelda (0.70) travel high distance to health facility/center than Wara Gesa (0.67). Mela Gelda recorded a higher percentage (44.8) of households with family member got chronic illness due to climate variability induced hazards than Wara Gesa (34.2). Households in Mela Gelda also reported that a higher percentage (52.4) of malaria in their locality than Wara Gesa (37.3). Mela Gelda also showed a higher vulnerability on the 
knowledge and skills indexed major component (0.72) than Wara Gesa (0.63), these were caused by lower years spent on the education of household heads for Mela Gelada (0.89) than Wara Gesa (0.55), and a large percentage of household heads never got vocational training about climate adaptation strategies for Mela Gelda (62.7) than Wara Gesa (58.3). Household heads of Mela Gelda also reported a higher percentage (85.7) had no information about climate variability and natural hazards than Wara Gesa (62.3).

The vulnerability index of the major components of the socio-demographic profile showed that Mela Gelda (0.50) was more vulnerable than Wara Gesa (0.46); these were because of a higher dependency ratio of households in Mela Gelda(0.72) than Wara Gesa (0.56). This could be explained by the fact that the population proportions under 15 and over 65 years that were dependent were greater in Mela Gelda than in Wara Gesakebele. And, high percentages of female-headed households were found in Mela Gelda (25.2) than Wara Gesa (15.7), and a higher average family member in Mela Gelda (0.69) than Wara Gesa (0.62). Similarly, FGDs discussants and key informant interviewers in Mela Gelda suggested that large family size may contribute to households' vulnerability to climate variability induced risks in the case of limited rural livelihood options.

\subsubsection{Natural Capital Vulnerability}

Climate variability has a higher effect on agricultural land, forests, and water, which are the essential source of rural livelihood sustainability. Climate variability's shortage of natural resources enhances resource-dependent conflict (Thakur \& Bajagain, 2019). The indexed natural capital consisted of three major components as indicated in table 4. The results of the natural capital of LVI standardized average scores in Wara Gesa (0.73) a higher than Mela Gelda (0.62). Land is an important natural capital and indicator of wealth. In this study, agricultural lands found in sloppy and erosion prone areas, farmers didn't practice structural SWC measures are considered as indicators to measure vulnerability. The major components of land resources were found to be higher vulnerable to climate variability and natural hazards in Wara Gesa (0.69) than Mela Gelda (0.49). When indicators reviewed the major components land resources, Wara Gesa was the most vulnerable in terms of house heads reported high percent rate of soil erosion in Wara Gesa (75) than Mela Gelda (53), having a high percent of farmlands in a sloppy area in Wara Gesa (84) than Mela Gelda (52) and a higher percentage of household heads who didn't practice physical soil and water conservation measures in Wara Gesa (49) than Mela Gelda (42). Moreover, during FGDs the participants reported the most of farmlands situated rugged topography and sloppy area these causes a high rate of soil erosions. 
In addition, when the total standardized weighted scores of the indicators of forest resources showed that Mela Gelda (0.53) was less vulnerable than Wara Gesa (0.73). These were because of the large percentage of households depending on forest resources recorded in Wara Gesa (73) than Mela Gelda (54). In comparison, the highest percentage of households reported that about a change of tree cover and severe damage to common forests in Mela Gelda than Wara Gesa. The key informant interviewee realized the farmers located near the main roads and close to the market place clear forests because charcoal is their income source.Wara Gesa (0.74) showed a slightly higher vulnerability standardized score in terms of water resources than Mela Gelda (0.70) on this aggregated major component. The indicators of water resources were more vulnerable to climate-induced natural hazards due to a high percentage of households reporting water conflict in past years and households to utilize water from unprotected sources.

\subsubsection{Financial Capital Vulnerability}

As indicated in table 4, the indexed financial capital such as income and wealth considered as major components to measure vulnerability. The aggregated indicators' overall standardized average score was shown to be more vulnerable in Mela Gelda (0.60) than Wara Gesa (0.55) to climate variability induced natural hazards. Mela Gelda (0.66) showed a slightly higher vulnerability in terms of indicators of average yearly off-farm income than Wara Gesa (0.60), a large percentage of households did not have off-farm employment in Mela Gelda(34.5) than Wara Gesa (28.4). About (46.7) percent of Mela Gelda households reported that they had no access to credit than Wara Gesa (36.2). Results from the survey showed households' average livestock ownership in TLU of households for Mela Gelda (1.66) was less vulnerable than Wara Gesa (1.23), and the average land hold size of households for Mela Gelda (1.87) was less vulnerable than Wara Gesa (1.42).

\subsubsection{Physical Capital Vulnerability}

As shown in table 4, the indexed physical capital consisted of two major components and seven indicators. WaraGesa showed a slightly higher vulnerability $(0.72)$ on the physical capital standardized score than Mela Gelda (0.69). Results from the survey showed the percentage of households with a house roof made of grass of (35) percent for Wara Gesa and (24.5) for Mela Gelda. Other indicators were the highest percentage of households' crops and houses affected by flood in the last 5 years for Wara Gesa (37.4) were more vulnerable to climate variability than Mela Gelda (18.6). About (82.7) percentage of Wara Gesa households reported their houses located in hazard-prone /slope areas and more vulnerable 
than Mela Gelda (56.7). In addition, FGDs discussants suggested most households are engaged in agricultural activities in sloppy areas, but the majority of the households have no plans to protect floods along with rugged topography. By road infrastructure on households' vulnerability to climate variability, the results suggest that levels of vulnerability in WaraGesa (0.72) were slightly highest than WaraGesa (0.69). The cause of the road vulnerability is that a large percentage of households had no transport access all year, and public roads challenged them.

\subsubsection{Social Capital Vulnerability}

Social capitals such as social networks and relationships, organizational membership, policy and leadership, and service delivery are affected by extreme weather events and natural climatic hazards due to which they have to adjust their social partnership, delay the delivery of services, often make the rural households dispute with the leader due to natural disaster management. As revealed in table 4, the indexed social capital consisted of three major components and nine specific indicators. The vulnerability standardized average score of the social capital major components showed that Mela Gelda (0.64) was more vulnerable to climatic-induced natural hazards than Wara Gesa (0.59).

When indicators reviewed the major components networks and relationships, Wara Gesa was the most vulnerable in terms of households' heads reported that a high percentage of household heads not associated with any organization/cooperative in Wara Gesa (75.3) than Mela Gelda (37.5), and a higher percentage of household heads had loose ties to relatives/neighbors in Wara Gesa (23) than Mela Gelda (12). By organization affiliation on households' vulnerability to climate variability, the results show that levels of vulnerability in WaraGesa (0.38) was highest vulnerable to climate-induced natural hazards than Mela Gelda (0.20), this was because of a high percentage of households not a member of the organization like idir and ikub, etc.

\subsubsection{Livelihood Strategies Vulnerability}

The indexed livelihood strategies component /profile consisted of four subcomponents/indicators. Considering the percentage of households dependent exclusively on agriculture as a source of income as an indicator a higher vulnerable in Mela Gelda (83) than Wara Gesa (62.4), and average inverse agricultural livelihood diversification index a higher vulnerable in Wara Gesa (0.685) than Mela Gelda (0.50). Wara Gesa (54\%) shows a slightly greater vulnerability to climate variability based on the percentage of households unable to save crops for contingency than Mela Gelda (52\%). Wara Gesa also showed greater 
vulnerability $(77.4 \%)$ on the percentage of households categorized themselves poor than Mela Gelda (63\%).

Table 4. Summary of the LVI result for indexed major components, and capitals and profile formula Gelda and Wara Gesa

\begin{tabular}{|c|c|c|c|c|}
\hline \multirow{2}{*}{ Indexed major components } & \multirow{2}{*}{$\begin{array}{l}\text { Number of } \\
\text { indicators }\end{array}$} & \multirow{2}{*}{$\begin{array}{c}\text { Indexed capitals and } \\
\text { profile }\end{array}$} & \multicolumn{2}{|c|}{ Standardized average score } \\
\hline & & & Mela Gelda & Wara Gesa \\
\hline Health & 3 & & & \\
\hline Skills and knowledge & 4 & Human & 0.59 & 0.52 \\
\hline Socio-demographic profile & 3 & & & \\
\hline Land resources & 3 & & & \\
\hline Forest resources & 3 & Natural & 0.62 & 0.73 \\
\hline Water & 3 & & & \\
\hline Income and wealth & 6 & Financial & 0.61 & 0.56 \\
\hline Housing & 3 & & & \\
\hline Road infrastructure & 4 & Physical & 0.53 & 0.62 \\
\hline Networks and relationships & 2 & & & \\
\hline Organizational affiliation & 3 & Social & 0.38 & 0.50 \\
\hline Policy and leadership services & 4 & & & \\
\hline Livelihood strategies & 4 & Livelihood strategies & 0.62 & 0.65 \\
\hline Total average LVI & - & - & 0.56 & 0.60 \\
\hline
\end{tabular}
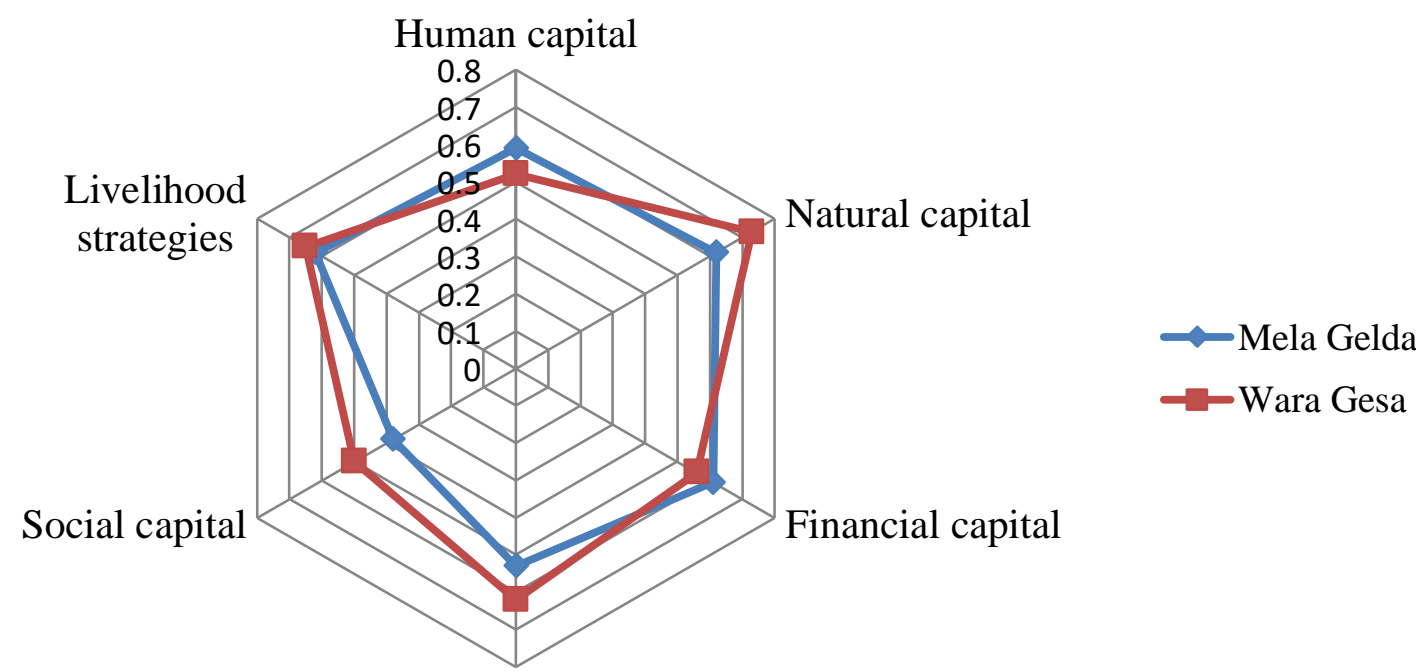

Physical capital

Figure 5. Spider Diagram of the indexed capitals and components of the LVI 


\subsubsection{LVI-IPCC Contributing Factors and Indexed Components}

Based on similar indicators that calculate their respective methods of the LVI-IPCC contributing factors were computed by grouping exposure, sensitivity, and adaptive capacity into three groups (Table 5). The LVI-IPCC contributing factors in the study area showed households for Mela Gelada (0.64) have a higher standardized average score than Wara Gesa (0.57). According to the IPCC classification of vulnerability exposure to natural hazards caused by climate variability was a high contributing factor for rural households. Yet, Wara Gesa households (0.55) have a greater capacity for adaptation than MelaGelda (0.47). The sensitivity contributing factor value for Wara Gesa (0.60) is slightly lesser than that of the Mela Gelda (0.62) indicating that Mela Gelda was more sensitive than Wara Gesa. The standardized weighted result of the overall LVI-IPCC score was for Mela Gelda (0.105) and for Wara Gesa (0.012), indicating that the showing of the incidence of great vulnerable conditions of rural households to climate variability-induced natural hazards in the district which is a similar result to that of the LVI standardized weighted scores.

Table 5. LVI-IPCC contributing factors calculation for households (Mela Gelda \& Wara Gesa)

\begin{tabular}{llccc}
\hline $\begin{array}{c}\text { IPCC contributing } \\
\text { factors to } \\
\text { vulnerability }\end{array}$ & Indexed major components & $\begin{array}{c}\text { Number of } \\
\text { indicators }\end{array}$ & $\begin{array}{c}\text { Mela } \\
\text { Gelda }\end{array}$ & Wara Gesa \\
\hline Exposure (e) & $\begin{array}{l}\text { Natural hazards and climate } \\
\text { variability }\end{array}$ & 5 & 0.64 & 0.57 \\
Adaptive capacity (a) & $\begin{array}{l}\text { Socio-demographic profile } \\
\text { Livelihood strategies }\end{array}$ & 3 & & \\
& Social networks & 4 & 0.47 & 0.55 \\
Sensitivity (s) & Health, knowledge and skills & 7 & & \\
& Natural capitals & 9 & 0.62 & 0.60 \\
& Financial capital\& wealth & 6 & & \\
LVI-IPCC value & & & 0.105 & 0.012 \\
\hline
\end{tabular}

Note : LVI-IPCC $=[$ Exposure-Adaptive capacity $] \times$ Sensitivity

Figure 6 also shows the vulnerability triangle that plots scores of contributing factors for adaptive capacity, exposure, and sensitivity. The vulnerability triangle reveals that the livelihoods in agricultural land of rural households in Wara Gesa were more vulnerable in terms of household adaptations' capacity considering the major components of the sociodemographic profile, livelihood strategies, and social networks. The rural livelihoods in agricultural land of households in Mela Gelda were more exposed than Wara Gesa to climate variability and slightly sensitive to climate variability, taking into consideration of the health, and knowledge and skills, natural capitals, and financial capitals of the households in the study area. 


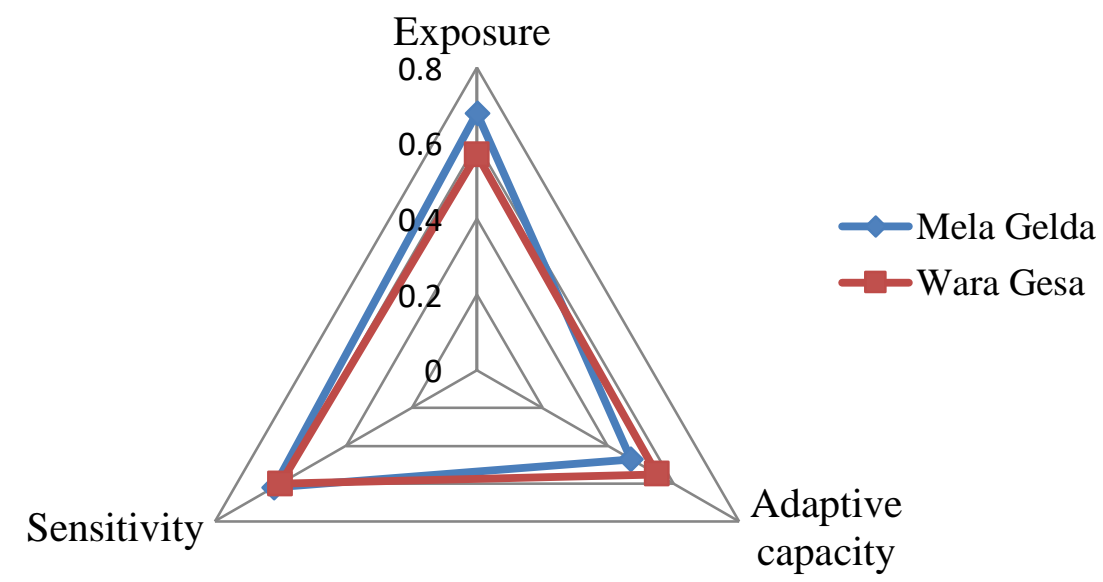

Figure 6. Vulnerability triangle of LVI-IPCC contributing factors

\section{Conclusion}

Rural households in Mela Gelda were a higher vulnerable than those in Wara Gesa in terms of indexed major components such as health, skill, and knowledge, socio-demographic profile, income and wealth, policy and leadership services. In comparison, farm households in Wara Gesa were more vulnerable in terms of land resources, forest resources, water resources, networks and relationships, organizational affiliation, and livelihood strategies. The livelihoods in agricultural land of rural households in Wara Gesa were more vulnerable in terms of the capacity for household adaptations considering socio-demographic profile, livelihood strategies, and social networks. The rural households in Mela Gelda also more exposed than Wara Gesa to climate variability and slightly sensitive to climate variability, considering the health, knowledge and skills, natural capitals, and financial capitals of the households in the study area. Hence, interventions including road infrastructure construction, integrated with watershed management, specific area early warning information system, livelihood diversification, afforestation/reforestation, and land degradations rehabilitation should be a better response to climate variability-induced natural hazards in the study area.

\section{Conflict of Interest}

The authors declare that there is no conflict of interest.

\section{Acknowledgments}

The authors would like to thank the Tercha district agricultural offices experts for their support in providing the necessary data for the study. In addition, we have enormously benefited from the study communities, and they shared for us their knowledge and experiences with patience without the feeling of tiredness. We also wish to thanks the 
Regional Meteorological Agency (Hawassa station) and zonal agricultural offices fortheir assistance in giving necessary data.

\section{References}

Abebe, Z. T. (2014). The potentials of local institutions for sustainable rural livelihoods: the case of farming households in Dawuro Zone, Ethiopia. Public Policy and Administration Review, 2(2), 95-129.

Ademe, D., Ziatchik, B. F., Tesfaye, K., Simane, B., Alemayehu, G., \&Adgo, E. (2020). Climate trends and variability at adaptation scale: Patterns and perceptions in an agricultural region of the Ethiopian Highlands. Weather and Climate Extremes, 100263. https://doi.org/10.1016/j.wace.2020.100263.

Adu, D. T., Kuwornu, J. K., Anim-Somuah, H., \& Sasaki, N. (2018). Application of livelihood vulnerability index in assessing smallholder maize farming households' vulnerability to climate change in Brong-Ahafo region of Ghana. Kasetsart Journal of Social Sciences, 39(1), 22-32. https://doi.org/10.1016/j.kjss.2017.06.009.

Amuzu, J., Kabo-Bah, A. T., Jallow, B. P., \&Yaffa, S. (2018). Households' Livelihood Vulnerability to Climate Change and Climate Variability: A Case Study of the Coastal Zone, The Gambia. Journal of Environment and Earth Science, 8(1), 35-46. https://doi.org/10.13140/RG.2.2.36057.42081.

Araro, K., Legesse, S. A., \& Meshesha, D. T. (2020). Climate Change and Variability Impacts on Rural Livelihoods and Adaptation Strategies in Southern Ethiopia. Earth Systems and Environment, 4(1), 15-26. https://doi.org/10.1007/s41748-019-00134-9

Asfaw, A., Simane, B., Hassen, A., Bantider, A. (2018). Variability and time series trend analysis of rainfall and temperature in north Central Ethiopia: a case study in Woleka sub-basin. Weather and Climate Extremes, 19, 29-41. https://doi.org/10.1016/j.wace.2017.12.002

Asrat, P., \& Simane, B. (2017). Characterizing vulnerability of crop-based rural systems to climate change and variability: agro-ecology specific empirical evidence from the Dabus watershed, north-West Ethiopia. American Journal of Climate Change, 6(4), 643-667.DOI: 10.4236/ajcc.2017.64033.

Azene, Y. B., Zeleke, M. T., \& Chekole, A. B. (2018). Vulnerability of mountain communities to climate change and natural resources scarcity in Northwest Ethiopia: the case of Debark Woreda. Journal of Degraded and Mining Lands Management, 6(1), 1467. https://doi.org/10.15243/JDMLM.2018.061.1467.

Teshome', M., \& Baye, A. (2018). Climate variability, communities' perceptions and land management strategies in Lay Gayint Woreda, Northwest Ethiopia. Journal of Degraded and Mining Lands Management, 5(3), 1217-1235. https://doi.org/10.15243/jdmlm.2018.053.1217.

Bore, G., \& Bedadi, B. (2015). Impacts of land use types on selected soil physico-chemical properties of Loma Woreda, Dawuro Zone, Southern Ethiopia. Science, Technology and Arts Research Journal, 4(4), 40-48. DOI: http://dx.doi.org/10.4314/star.v4i4.6. 
Can, N. D., Tu, V. H., \& Hoanh, C. T. (2013). Application of livelihood vulnerability index to assess risks from flood vulnerability and climate variability: A case study in the Mekong Delta of Vietnam. Journal of Environmental Science and Engineering, 2(8), 476-86.

Conway, D., \& Schipper, E. L. F. (2011). Adaptation to climate change in Africa: Challenges and opportunities identified from Ethiopia. Global Environmental Change, 21(1), 227-237.doi: 10.1016/j.gloenvcha.2010.07.013.

Dendir, Z., \& Simane, B. (2019). Livelihood vulnerability to climate variability and change in different agroecological zones of Gurage Administrative Zone, Ethiopia. Progress in Disaster Science, 3, 100035.https://doi.org/10.1016/j.pdisas.2019.100035.

Dercon S. Hoddinott J. Woldehanna T. (2005). Vulnerability and shocks in 15 Ethiopian villages, 1999-2004. J Afr Econ, 14:559-585.

Deressa, T. T., Hassan, R. M., \& Ringler, C. (2009). Assessing household vulnerability to climate change The Case Of Farmers In The Nile Basin Of Ethiopia (Vol. 935). Washington : Intl Food Policy Res Inst.

Deressa, T., Hassan, R. M., \& Ringler, C. (2008). Measuring Ethiopian farmers' vulnerability to climate change across regional states. Washington : Intl Food Policy Res Inst.

Dessai, S., \& Hulme, M. (2004). Does climate adaptation policy need probabilities? Climate Policy, 4(2), 107-128. https://doi.org/10.1080/14693062.2004.9685515.

Echeverría, D., \& Terton, A. (2016). Review of current and planned adaptation action in Ethiopia. Retrieved from https://idl-bnc-idrc.dspacedirect.org/handle/10625/55864.

Endalew, H. A., \& Sen, S. (2020). Effects of climate shocks on Ethiopian rural households: an integrated livelihood vulnerability approach. Journal of Environmental Planning and Management, 64(3), 399-431. https://doi.org/10.1080/09640568.2020.1764840.

Fellmann, T. (2012). The assessment of climate change-related vulnerability in the agricultural sector: reviewing conceptual frameworks. Paper presented at FAO/OECD Workshop. Rome, Italy.

Few, R., Satyal, P., McGahey, D., Leavy, J., Budds, J., Assen, M., ...\& Bewket, W. (2015). Vulnerability and adaptation to climate change in the semi-arid regions of East Africa. Retrieved from https://idl-bnc-idrc.dspacedirect.org/handle/10625/57427.

Folke, C. (2006). Resilience: The emergence of a perspective for social-ecological systems analyses. Global Environmental Change, 16(3), 253-267. https://doi.org/10.1016/j.gloenvcha.2006.04.002.

Ford, J.D., Keskitalo, E.C.H., Smith, T., Pearce, T., Berrang-Ford, L., Duerden, F. and Smit, B. (2010). Case study and analogue methodologies in climate change vulnerability research. Chicester, UK : John Wiley and Sons, Ltd.

Gezie, M. (2019). Farmer's response to climate change and variability in Ethiopia: A review. Cogent Food \& Agriculture, 5(1), 1613770. https://doi.org/10.1080/23311932.2019.1613770. 
Gitima, G. \& Legesse, A. (2019). Determinants of Farmers' Decision to Use Improved Land Management Practice in Gindara Watershed, Southern Ethiopia. Ethiopian Journal of Environment and Development, 2(2); 17-34.

Hahn, M. B., Riederer, A. M., \& Foster, S. O. (2009). The Livelihood Vulnerability Index: A pragmatic approach to assessing risks from climate variability and change-A case study in Mozambique. Global Environmental Change, 19(1), 74-88. https://doi.org/10.1016/j.gloenvcha.2008.11.002.

Huai, J. (2016). Role of livelihood capital in reducing climatic vulnerability: insights of Australian Wheat from 1990-2010. PloS one, 11(3). https://doi.org/10.1371/journal.pone.0152277.

Huong, N. T. L., Yao, S., \& Fahad, S. (2019). Assessing household livelihood vulnerability to climate change: The case of Northwest Vietnam. Human and Ecological Risk Assessment: An International Journal, 25(5), 1157-1175. https://doi.org/10.1080/10807039.2018.1460801.

IPCC. (2018). Emissions Scenarios: Summary for Policymakers. A Special Report of IPCC Working Group III. Published for the Intergovernmental Panel on Climate Change, Retrieved from www.ipcc.ch.

IPCC, (2014). Summary for policy makers. "Climate change 2013: The Physical Science Basis", Contribution of Working Group I to the Fifth Assessment Report of the Intergovernmental Panel on Climate Change. Cambridge : Cambridge University Press.

Kedir, H., \& Tekalign, S. (2016). Climate variability and livelihood strategies pursued by the pastoral community of the karrayu people, Oromia region, Central Ethiopia. East African Journal of Sciences, 10(1), 61-70.

Ketema, A. M., \& Negeso, K. D. (2020). Effect of climate change on agricultural output in Ethiopia. Jurnal Perspektif Pembiayaan Dan Pembangunan Daerah, 8(3), 195-208. https://doi.org/10.22437/ppd.v8i3.9076.

Krishnamurthy, P. K., Lewis, K., \& Choularton, R. J. (2014). A methodological framework for rapidly assessing the impacts of climate risk on national-level food security through a vulnerability index. Global Environmental Change, 25(1), 121-132. https://doi.org/10.1016/j.gloenvcha.2013.11.004.

Marelign, A., Addisu, S., \& Mekuriaw, A. (2019). Observed and Perceived Climate Change and Variability and Small Holder Farmers' Vulnerability: The Case of Janamora District, Northwestern Ethiopia. Journal of Environment and Earth Science. https://doi.org/10.7176/JEES/9-8-04.

Masuda, Y. J., Castro, B., Aggraeni, I., Wolff, N. H., Ebi, K., Garg, T., ... Spector, J. (2019). How are healthy, working populations affected by increasing temperatures in the tropics? Implications for climate change adaptation policies. Global Environmental Change, 56(C), 29-40. https://doi.org/10.1016/j.gloenvcha.2019.03.005.

Mekonnen, Z., woldeamanuel, T., \& kassa, H. (2019). Socio-ecological vulnerability to climate change/variability in central rift valley, Ethiopia. Advances in Climate Change Research, 10(1), 9-20. https://doi.org/10.1016/j.accre.2019.03.002. 
Mohammed, R., \& Scholz, M. (2019). Climate Variability Impact on the Spatiotemporal Characteristics of Drought and Aridityin Arid and Semi-Arid Regions. Water Resources Management, 33(15), 5015-5033. https://doi.org/10.1007/s11269-01902397-3.

National Meteorological Agency. (2007). Climate change national adaptation programme of $\begin{array}{llll}\text { action }(N A P A) & \text { Ethiopia. } & \text { Retreived }\end{array}$ https://www.preventionweb.net/files/8522_eth01.pdf.

National Meteorological Agency. (2019). Weather \& Climate information. Retreived from www.ethiomet.gov.et.

Narayanan, K., \& Sahu, S. K. (2016). Effects of climate change on household economy and adaptive responses among agricultural households in eastern coast of India. Current Science, 110(7), 1240-1250-1250. https://doi.org/10.18520/cs/v110/i7/1240-1250.

Neupane, N., Murthy, M. S. R., Rasul, G., Wahid, S., Shrestha, A. B., \& Uddin, K. (2013). Integrated biophysical and socioeconomic model for adaptation to climate change for agriculture and water in the Koshi Basin. Handbook of Climate Change Adaptation; Berlin, Germany : Springer.

Ofoegbu, C., Chirwa, P., Francis, J., \& Babalola, F. (2017). Assessing vulnerability of rural communities to climate change: A review of implications for forest-based livelihoods in South Africa. International Journal of Climate Change Strategies and Management, 9(3), 374-386. https://doi.org/10.1108/IJCCSM-04-2016-0044.

Panthi, J., Aryal, S., Dahal, P., Bhandari, P., Krakauer, N. Y., \& Pandey, V. P. (2016). Livelihood vulnerability approach to assessing climate change impacts on mixed agrolivestock smallholders around the Gandaki River Basin in Nepal. Regional Environmental Change, 16(4), 1121-1132. https://doi.org/10.1007/s10113-015-0833y.

Paul, A., Deka, J., Gujre, N., Rangan, L., \& Mitra, S. (2019). Does nature of livelihood regulate the urban community's vulnerability to climate change? Guwahati city, a case study from North East India. Journal of Environmental Management, 251 (C), 109591. https://doi.org/10.1016/j.jenvman.2019.109591.

Simane, B., Zaitchik, B. F., \& Foltz, J. D. (2016). Agroecosystem specific climate vulnerability analysis: application of the livelihood vulnerability index to a tropical highland region. Mitigation and Adaptation Strategies for Global Change, 21(1), 3965. https://doi.org/10.1007/s11027-014-9568-1

Sujakhu, N. M., Ranjitkar, S., He, J., Schmidt-Vogt, D., Su, Y., \& Xu, J. (2019). Assessing the livelihood vulnerability of rural indigenous households to climate changes in Central Nepal, Himalaya. Sustainability, 11(10), 1-18. https://doi.org/10.3390/su11102977.

Suryanto, S., \& Rahman, A. (2019). Application of livelihood vulnerability index to assess risks for farmers in the Sukoharjo regency and Klaten regency, Indonesia. Jàmbá Journal of Disaster Risk Studies, 11(1), 1-9. https://doi.org/10.4102/jamba.v11i1.739.

Tanner, T., Lewis, D., Wrathall, D., Bronen, R., Cradock-Henry, N., Huq, S., ... Thomalla, F. (2015). Livelihood resilience in the face of climate change. Nature Climate Change, 5(1), 23-26. https://doi.org/10.1038/nclimate2431. 
Teshome, M. (2016). Rural households' agricultural land vulnerability to climate change in Dembia woreda, Northwest Ethiopia. Environmental Systems Research, 5(1), 1-18. https://doi.org/10.1186/s40068-016-0064-3.

Teshome, M. (2017). Perceived Human Health Vulnerability to Climate Change in DembiaWoreda of Tana Basin, Northwest Ethiopia. Ethiopian Renaissance Journal of Social Sciences and the Humanities, 4(2).

Thakur, S. B., \& Bajagain, A. (2019). Impacts of Climate Change on Livelihood and its Adaptation Needs. Journal of Agriculture and Environment, 20, 173-185. https://doi.org/10.3126/aej.v20i0.25067.

Turpie, J., \& Visser, M. (2013). The impact of climate change on South Africa's rural areas. Financial and Fiscal Commission, 14, 100-160.

Ullah, W., Nihei, T., Nafees, M., Zaman, R., \& Ali, M. (2018). Understanding climate change vulnerability, adaptation and risk perceptions at household level in Khyber Pakhtunkhwa, Pakistan. International Journal of Climate Change Strategies and Management, 10(3), 359-378. https://doi.org/10.1108/IJCCSM-02-2017-0038.

World Meteorological Organization (2012). Standardized precipitation index user guide. Retreived from http://www.wamis.org/agm/pubs/SPI/WMO_1090_EN.pdf.

Young, G., Zavala, H., Wandel, J., Smit, B., Salas, S., Jimenez, E., ... Cepeda, J. (2009). Vulnerability and adaptation in a dryland community of the Elqui Valley, Chile. Climatic Change, 98(1-2), 245-276. https://doi.org/10.1007/s10584-009-9665-4. 